\title{
Effect of manure, clay, charcoal, zeolite, and calcium oxide on some properties of soil contaminated with cobalt
}

\begin{abstract}
The study has been undertaken in order to determine the influence of different substances (manure, clay, charcoal, zeolite and calcium oxide) on soil $\mathrm{pH}$, hydrolytic acidity, total exchangeable bases, cation exchange capacity, the base saturation of soil contaminated with cobalt $\left(0,20,40,80,160,320 \mathrm{mg} \cdot \mathrm{kg}^{-1}\right.$ of soil). The analysed properties of soil proved to be dependent on the cobalt contamination and the kind of substances. In the series without substances soil contamination with the highest doses of cobalt raised the soil's hydrolytic acidity but depressed its $\mathrm{pH}$, total exchangeable bases and base saturation. Among the substances applied to soil in order to neutralize the effect of contamination with cobalt, calcium oxide had the strongest influence on the soil's properties. In the series with calcium oxide application the hydrolytic acidity was decreased and other soil properties were increased. Manure addition to soil had positive but weaker effect on analysed soil properties.
\end{abstract}

Keywords: cobalt, doses, substances, soil properties

\section{INTRODUCTION}

The acceptable content of cobalt as well as the remaining metals occurring in the soil positively affects its physical and chemical properties and therefore the proper development of each level of the trophic chain (Hinojosa et al. 2004, Wyszkowski and Wyszkowska 2009, Hu et al. 2013). According to the Regulation of the Minister of the Environment of 1 September 2016 (Rozporzadzenie 2016) on the way of performing the assessment of the contamination of the earth surface, the acceptable content of cobalt in the soil for group I of land amounts to $50 \mathrm{mg} \cdot \mathrm{kg}^{-1}$, group II - (I-20 mg $\mathrm{kg}^{-1}$, II - $30 \mathrm{mg} \cdot \mathrm{kg}^{-1}$, III - 50 $\mathrm{mg} \cdot \mathrm{kg}^{-1}$ ), group III $-100 \mathrm{mg} \cdot \mathrm{kg}^{-1}$, and group IV $200 \mathrm{mg} \cdot \mathrm{kg}^{-1}$ of soil. In Polish soils, the content of cobalt occurs in values not exceeding its acceptable threshold in all of the said groups specified in the aforementioned Regulation. It was estimated to vary from 0.11 to $6.76 \mathrm{mg} \cdot \mathrm{kg}^{-1}$ on average. At the global scale, the content of cobalt considerably exceeds the recorded values in comparison to Polish soils. The values reach even $1000 \mathrm{mg} \cdot \mathrm{kg}^{-1}$ (Toxicological Profile for Cobalt 2004). High contents of the element in soil usually occur in places of its extraction, coal combustion, and car fuels combustion (Biswas et al. 2013, Huang et al. 2013). The content of cobalt in the air varies from 1 to $10 \mathrm{ng} \cdot \mathrm{m}^{3}$. The closer the value is to $10 \mathrm{ng} \cdot \mathrm{m}^{3}$, the more it is characteristic of industrial areas (Elinder 1984, Nilsson et al. 1985).
Mean content of cobalt subject to deposition with atmospheric precipitation to the soil surface of rural areas amounts to $0.3 \mu \mathrm{g} \cdot \mathrm{dm}^{3}$, and in areas characterised by high level of industrialisation it reaches up to 1.7 $\mu \mathrm{g} \cdot \mathrm{dm}^{3}$ (Arimoto et al. 1985, Hansson et al. 1988).

Sorption of cobalt occurs on different type of components belonging to the solid phase of the soil, such as loamy minerals, iron oxides, and manganese oxides. Chelate compounds of the metal particularly contribute to an increase in its mobility and maintenance of the acidic reaction. With an increase in the soil reaction, its mobility considerably decreases (Kabata-Pendias and Pendias 2001). The content of organic matter in soil, increasing with its decomposition, also strongly contributes to a reduction of its mobility (Labętowicz and Rutkowska 2001). As a result of exceeding its acceptable content in the soil solution, plants begin to wilt, and necroses and chloroses appear on the leaves. In legume plants, excessive content of cobalt can result in the inhibition of the process of binding hydrogen (Jain and Nainawatee 2000, Chatterjee and Chatterjee 2002). It is therefore important to limit the effect of the element on the properties of soil and plants.

Due to this, research was conducted for the purpose of determination of the effect of selected substances limiting the impact of cobalt on the $\mathrm{pH}$, hydrolytic acidity, total exchangeable bases, cation exchange capacity, and base saturation of soil. 


\section{MATERIAL AND METHODOLOGY}

The study was based on a pot experiment conducted in a vegetation hall belonging to the University of Warmia and Mazury in Olsztyn. It was conducted on soil with reaction of 5.05 prior to the establishment of the experiment in $1 \mathrm{M} \mathrm{KCl}$, hydrolytic acidity of $28.40 \mathrm{mmol}_{(+)} \cdot \mathrm{kg}^{-1}$, total exchangeable bases of 46.50 $\mathrm{mmol}_{(+)} \cdot \mathrm{kg}^{-1}$, cation exchange capacity of 74.90 $\mathrm{mmol}_{(+)} \cdot \mathrm{kg}^{-1}$, and base saturation of $68.08 \%$. It was eutrophic brown soil with the granulometric composition of loamy sand and the following content of particular fractions: sand $(>0.05 \mathrm{~mm})-73.9 \%$, dust $(0.02-0.05 \mathrm{~mm})-24.1 \%$, and clay $(<0.002 \mathrm{~mm})-$ $2.0 \%$. The content of organic carbon amounted to $14.10 \mathrm{~g} \cdot \mathrm{kg}^{-1}$.

The volume of polyethylene pots used for the experiment amounted to $9 \mathrm{~kg}$ of soil. The experiment, taking into account two factors, was conducted in three repetitions. The factor of the first order were increasing doses of cobalt: $0,20,40,80,160,320$ $\mathrm{mg} \cdot \mathrm{kg}^{-1}$ of soil introduced in the form of cobalt chloride. Acceptable contents of cobalt specified in the Regulation of the Minister of the Environment of 2016 on the manner of performing the assessment of the contamination of the earth surface provided the basis for the selection of doses applied in the experiment. The factor of the second order covered substances used for the purpose of reducing the effect of cobalt on the soil and test plants: manure, clay, charcoal, zeolite (applied to the amount of $2 \%$ in comparison to the mass of soil in the pot), and calcium oxide (in a dose corresponding to $1 \mathrm{HAC}$ ). The aforementioned substances were chosen particularly due to their positive effect in terms of improvement of the physical and chemical soil properties. Manure was used, because it contributes to an increase in the content of organic matter in soil. Clay increases the volume of the soil sorption complex. Charcoal increases the content of carbon in soil and shows adsorptive properties. Zeolite increases the porousness of soil, and shows ion exchange properties. Calcium oxide in turn causes an increase in soil reaction. The dose of the substances was determined based on pilot research conducted before. Moreover, identical amounts of nutrients were added once to each pot: $100 \mathrm{mg} \mathrm{N}$ $\left(\mathrm{NH}_{4} \mathrm{NO}_{3}\right) ; 35 \mathrm{mg} \mathrm{P}\left(\mathrm{KH}_{2} \mathrm{PO}_{4}\right) ; 100 \mathrm{mg} \mathrm{K}(\mathrm{KCl})$; $50 \mathrm{mg} \mathrm{Mg}\left(\mathrm{MgSO}_{4} 7 \mathrm{H}_{2} \mathrm{O}\right) ; 0.33 \mathrm{mg} \mathrm{B}\left(\mathrm{H}_{3} \mathrm{BO}_{3}\right)$; $5 \mathrm{mg} \mathrm{Mn}\left(\mathrm{MnCl}_{2} \cdot 4 \mathrm{H}_{2} \mathrm{O}\right)$, and $5 \mathrm{mg}$ Mo $\left(\left(\mathrm{NH}_{4}\right)_{6} \mathrm{Mo}_{7} \mathrm{O}_{24} 4 \mathrm{H}_{2} \mathrm{O}\right) \cdot \mathrm{kg}^{-1}$ of soil. Relevant doses of cobalt, substances, and nutrients were introduced to the soil at the moment of establishment of the experiment. Spring rape (Brassica napus L.) seeds of Legolas cultivar were sowed to the prepared soil, and after its harvest, corn seeds (Zea mays L.) of Tonacja cultivar. The harvest of the main plant was performed at the flowering stage, and the successive plant at the stage of intensive shoot growth. The vegetation period of spring rape lasted 54 days, and corn 75 days. After corn harvest, soil samples were collected. They were then dried and sieved through $1 \mathrm{~mm}$ mesh. The selection of test plants was particularly based on their high share in the crop structure both in Poland and around the world, and variable degree of sensitivity to contamination with cobalt. Corn is categorised as a cereal characterised by high sensitivity to the effect of cobalt. Spring rape is a cruciferous plant showing high tolerance to high contents of the metal.

Soil reaction in $1 \mathrm{M} \mathrm{KCl}$ was determined potentiometrically by means of a $\mathrm{pH}$ meter, and hydrolytic acidity (HAC) and total exchangeable bases (TEB) by means of the Kappen method (Ostrowska et al. 1991). Cation exchange capacity (CEC) was calculated based on the formula CEC=TEB $+\mathrm{HAC}$, and base saturation (BS) in accordance with the formula $\mathrm{BS}=(\mathrm{TEB} / \mathrm{CEC}) \cdot 100$ (Ostrowska et al. 1991). The results were processed statistically by means of two-factor variance analysis ANOVA from the Statistica package (StatSoft Inc. 2014).

\section{RESULTS AND DISCUSSION}

The factor of the first (increasing cobalt doses) as well as the second order (type of substance) applied in the experiment contributed to the change in the analysed soil properties. In control objects - with no addition of substances, the increasing cobalt doses reduced the $\mathrm{pH}$ value from 5.56 to $4.89(\mathrm{r}=0.956)$, and increased hydrolytic acidity from 26.30 to 35.44 $\mathrm{mmol}_{(+)} \cdot \mathrm{kg}^{-1}$ of soil $(\mathrm{r}=0.943)$ (Table 1$)$. The study by $\mathrm{Li}$ et al. (2009) shows that in soil with acidic $\mathrm{pH}$ (4.5), cobalt concentration in the soil solution varied from 0.01 to $367 \mathrm{mg} \cdot \mathrm{dm}^{-3}$, and in soil with alkaline $\mathrm{pH}$ (7.5) it was considerably lower, and ranged from $<0.001$ to $0.008 \mathrm{mg} \cdot \mathrm{dm}^{-3}$. In research by Kosiorek and Wyszkowski (2016a, 2016b), the highest cobalt doses caused a decrease in reaction, and an increase in the hydrolytic acidity of soil.

The introduction of considerable contents of the chloride salt of the discussed microelement caused an increase in the content of hydrogen ions in the soil solution and sorption complex, responsible for an increase in soil acidity. In own research in objects with no application of substances, the greatest decrease in total exchangeable bases was recorded in objects contaminated with cobalt in a dose of 160 (by 14\%) and $320 \mathrm{mg} \mathrm{Co} \cdot \mathrm{kg}^{-1}$ of soil (by 20\%), whereas a slight 
TABLE 1. pH value and hydrolytic acidity of soil

\begin{tabular}{|c|c|c|c|c|c|c|c|}
\hline \multirow{2}{*}{$\begin{array}{l}\text { Dose of cobalt } \\
\text { (mg.kg }{ }^{-1} \text { of soil) }\end{array}$} & \multicolumn{7}{|c|}{ Kind of substance neutralizing effect of cobalt } \\
\hline & $\begin{array}{l}\text { without } \\
\text { additions }\end{array}$ & manure & clay & charcoal & zeolite & $\begin{array}{l}\text { calcium } \\
\text { oxide }\end{array}$ & average \\
\hline \multicolumn{8}{|l|}{$\mathrm{pH}_{\mathrm{KCl}}$} \\
\hline 0 & 5.56 & 6.24 & 5.54 & 5.59 & 5.25 & 7.12 & \\
\hline 20 & 5.55 & 6.31 & 5.49 & 5.56 & 5.49 & 7.31 & \\
\hline 40 & 5.47 & 6.36 & 5.50 & 5.67 & 5.33 & 7.36 & \\
\hline 80 & 5.21 & 6.18 & 5.23 & 5.15 & 4.93 & 7.30 & \\
\hline 160 & 5.16 & 5.56 & 5.04 & 4.86 & 4.71 & 7.29 & \\
\hline 320 & 4.89 & 5.21 & 5.12 & 5.13 & 4.98 & 6.90 & \\
\hline $\mathrm{r}$ & $-0.956 * *$ & $-0.957 * *$ & $-0.806 * *$ & $-0.681 * *$ & $-0.611 * *$ & $-0.701 * *$ & \\
\hline LSD for & \multicolumn{7}{|c|}{ Co dose $-0.04^{* *}$; kind of substance $-0.04^{* *}$; interaction $-0.09^{* *}$} \\
\hline \multicolumn{8}{|c|}{ Hydrolytic acidity - HAC $\left(\mathrm{mmol}_{(+)} \cdot \mathrm{kg}^{-1}\right.$ of soil $)$} \\
\hline 0 & 26.30 & 23.31 & 26.93 & 25.20 & 30.40 & 14.96 & 24.52 \\
\hline 20 & 26.78 & 23.15 & 28.04 & 24.57 & 28.67 & 15.59 & 24.47 \\
\hline 40 & 28.51 & 22.21 & 26.62 & 24.10 & 28.51 & 14.96 & 24.15 \\
\hline 80 & 30.87 & 22.21 & 30.71 & 28.98 & 33.08 & 14.18 & 26.67 \\
\hline 160 & 33.55 & 29.30 & 32.76 & 30.24 & 35.28 & 14.33 & 29.24 \\
\hline 320 & 35.44 & 32.76 & 32.13 & 29.45 & 33.86 & 19.06 & 30.45 \\
\hline Average & 30.24 & 25.49 & 29.53 & 27.09 & 31.63 & 15.51 & 26.58 \\
\hline $\mathrm{r}$ & $0.943 * *$ & $0.932 * *$ & $0.803 * *$ & $0.749 * *$ & $0.718^{* *}$ & $0.752 * *$ & $0.939 * *$ \\
\hline LSD for & \multicolumn{7}{|c|}{ Co dose $-0.97^{* *}$; kind of substance $-0.97^{* *}$; interaction $-2.37^{* *}$} \\
\hline
\end{tabular}

Explanations significant for: ${ }^{* *} \mathrm{P}=0.01,{ }^{*} \mathrm{P}=0.05, \mathrm{r}-$ correlation coefficient.

increase was observed in soil to which cobalt was introduced in a dose of $20 \mathrm{mg} \cdot \mathrm{kg}^{-1}$ (Table 2). A low but significant increase in cation exchange capacity was observed in soil contaminated with a dose of 20 and $80 \mathrm{mg} \mathrm{Co} \cdot \mathrm{kg}^{-1}$ of soil, and in objects with higher doses of cobalt, its lower values were recorded. The introduction of increasing doses of cobalt to soil substantially contributed to a decrease in base saturation by $12 \%(\mathrm{r}=-0.958)$ (Table 2$)$. The occurrence of cobalt in soil contributes to a change of physical and chemical soil properties (Kukier et al. 2004, Li et al. 2004, Li et al. 2009). The correlation between the content of cobalt occurring in soil and its cation exchange capacity was also determined by Micó et al. (2008). In earlier research by Kosiorek and Wyszkowski (2016a, 2016b), contamination with cobalt caused a decrease in total exchangeable bases, cation exchange capacity, and base saturation. Changes in soil properties resulting from high content of cobalt considerably affect the intensity of its uptake by plants. According to Migaszewski and Gałuszka (2016), the acceptable content of cobalt in a plant varies from 13 to $50 \mathrm{mg} \cdot \mathrm{kg}^{-1}$, however the occurrence of cobalt at a level from 0.1 to $3 \mathrm{mg} \cdot \mathrm{kg}^{-1}$ can cause toxic changes in plants.
Among the applied substances, calcium oxide had the most beneficial effect on the analysed soil properties. In the series with its addition, soil $\mathrm{pH}$ increased to a value exceeding 7, and hydrolytic acidity decreased by $49 \%$ on average in comparison to objects with no substances (Table 1). Hydrogen ions occurring on the surface of soil particles were therefore replaced by calcium contained in calcium oxide, dissolved in the soil solution. Total exchangeable bases also considerably increased by $63 \%$ on average, as well as cation exchange capacity by $23 \%$, and base saturation by $21 \%$ (Table 2 ). Manure and charcoal were characterised by equally beneficial, however substantially weaker effect on the analysed soil properties in comparison to calcium oxide.

The effect of the remaining substances on the analysed soil properties was relatively low, and usually not significant. The highest increase in the content of organic carbon in soil in the discussed experiment was recorded in soil with an addition of charcoal, amounting to more than $16 \mathrm{~g} \cdot \mathrm{kg}^{-1}$.

Comparing objects contaminated with cobalt with objects with a dose of the highest contamination, the greatest reduction of $\mathrm{pH}$ values was observed in objects with an addition of manure (from 6.24 to 5.51), 
TABLE 2. Total exchangeable bases, cation exchange capacity and base saturation in soil

\begin{tabular}{|c|c|c|c|c|c|c|c|}
\hline \multirow{2}{*}{$\begin{array}{l}\text { Dose of cobalt } \\
\left(\mathrm{mg} \cdot \mathrm{kg}^{-1} \text { of soil) }\right.\end{array}$} & \multicolumn{7}{|c|}{ Kind of substance neutralizing effect of cobalt } \\
\hline & $\begin{array}{l}\text { without } \\
\text { additions }\end{array}$ & manure & clay & charcoal & zeolite & $\begin{array}{l}\text { calcium } \\
\text { oxide }\end{array}$ & average \\
\hline \multicolumn{8}{|c|}{ Total exchangeable bases - TEB $\left(\mathrm{mmol}_{(+)} \cdot \mathrm{kg}^{-1}\right.$ of soil) } \\
\hline 0 & 56.33 & 61.79 & 61.11 & 49.35 & 58.59 & 76.23 & 60.57 \\
\hline 20 & 61.32 & 71.14 & 63.53 & 57.91 & 51.03 & 97.39 & 67.05 \\
\hline 40 & 56.02 & 68.88 & 61.69 & 60.69 & 51.92 & 94.45 & 65.61 \\
\hline 80 & 58.33 & 66.31 & 58.17 & 49.61 & 52.50 & 91.40 & 62.72 \\
\hline 160 & 48.72 & 54.65 & 50.24 & 47.30 & 44.57 & 90.72 & 56.04 \\
\hline 320 & 45.15 & 46.88 & 46.83 & 52.45 & 45.99 & 81.74 & 53.17 \\
\hline Average & 54.31 & 61.61 & 56.93 & 52.89 & 50.77 & 88.66 & 60.86 \\
\hline $\mathrm{r}$ & $-0.895 * *$ & $-0.890 * *$ & $-0.947 * *$ & -0.276 & $-0.769 * *$ & -0.260 & $-0.850 * *$ \\
\hline LSD for & \multicolumn{7}{|c|}{ Co dose $-2.92 * * ;$ kind of substance $-2.92 * *$; interaction $-7.16^{* *}$} \\
\hline \multicolumn{8}{|c|}{ Cation exchange capacity $-\mathrm{CEC}\left(\mathrm{mmol}_{(+)} \cdot \mathrm{kg}^{-1}\right.$ of soil) } \\
\hline 0 & 82.63 & 85.10 & 88.04 & 74.55 & 88.99 & 91.19 & 85.08 \\
\hline 20 & 88.10 & 94.29 & 91.57 & 82.48 & 79.70 & 112.98 & 91.52 \\
\hline 40 & 84.53 & 91.09 & 88.31 & 84.79 & 80.43 & 109.41 & 89.76 \\
\hline 80 & 89.20 & 88.52 & 88.88 & 78.59 & 85.58 & 105.58 & 89.39 \\
\hline 160 & 82.27 & 83.95 & 83.00 & 77.54 & 79.85 & 105.05 & 85.28 \\
\hline 320 & 80.59 & 79.64 & 78.96 & 81.90 & 79.85 & 100.80 & 83.62 \\
\hline Average & 84.55 & 87.10 & 86.46 & 79.98 & 82.40 & 104.17 & 87.44 \\
\hline $\mathrm{r}$ & $-0.578 *$ & $-0.779 * *$ & $-0.933 * *$ & 0.159 & -0.465 & -0.096 & $-0.647 * *$ \\
\hline LSD for & \multicolumn{7}{|c|}{ Co dose $-2.92^{* *}$; kind of substance $-2.92^{* *}$; interaction $-7.16^{* *}$} \\
\hline \multicolumn{8}{|c|}{ Base saturation - BS (\%) } \\
\hline 0 & 68.17 & 72.61 & 69.41 & 66.20 & 65.84 & 83.59 & 70.97 \\
\hline 20 & 69.60 & 75.45 & 69.38 & 70.21 & 64.03 & 86.20 & 72.48 \\
\hline 40 & 66.27 & 75.62 & 69.86 & 71.58 & 64.55 & 86.33 & 72.37 \\
\hline 80 & 65.39 & 74.91 & 65.45 & 63.13 & 61.35 & 86.57 & 69.47 \\
\hline 160 & 59.22 & 65.10 & 60.53 & 61.00 & 55.82 & 86.36 & 64.67 \\
\hline 320 & 56.02 & 58.86 & 59.31 & 64.04 & 57.60 & 81.09 & 62.82 \\
\hline Average & 64.11 & 70.42 & 65.66 & 66.03 & 61.53 & 85.02 & 68.80 \\
\hline $\mathrm{r}$ & $-0.958 * *$ & $-0.934 * *$ & $-0.921 * *$ & $-0.547 *$ & $-0.828 * *$ & $-0.632 * *$ & $-0.933 * *$ \\
\hline LSD for & \multicolumn{7}{|c|}{ Co dose $-1.48^{* *}$; kind of substance $-1.48^{* *}$; interaction $-3.61^{* *}$} \\
\hline
\end{tabular}

Explanations significant for: ${ }^{* *} \mathrm{P}=0.01,{ }^{*} \mathrm{P}=0.05, \mathrm{r}-$ correlation coefficient.

and the lowest with an addition of calcium oxide (from 7.2 to 6.90 ). In objects with manure, also the greatest increase in hydrolytic acidity was recorded (from 23.31 to $32.76 \mathrm{mmol}_{(+)} \cdot \mathrm{kg}^{-1}$ of soil), and the lowest in objects with an addition of zeolite (from 30.40 to $33.86 \mathrm{mmol}_{(+)} \cdot \mathrm{kg}^{-1}$ of soil). Total exchangeable bases increased only in objects with an addition of calcium oxide (from 76.23 to $81.74 \mathrm{mmol}_{(+)} \cdot \mathrm{kg}^{-1}$ of soil) and charcoal (49.35 to $52.45 \mathrm{mmol}_{(+)} \mathrm{kg}^{-1}$ of soil). In the remaining objects, a decrease in total exchangeable bases was recorded. A similar tendency was observed in the case of cation exchange capacity (Table 2). Base saturation in all objects was reduced, particularly in objects with an addition of charcoal (from 72.61 to $58.86 \mathrm{mmol}_{(+)} \cdot \mathrm{kg}^{-1}$ of soil).
A similar effect of calcium oxide on the soil properties analysed in this paper was observed by Wyszkowski and Sivitskaya (2015) as well as Kosiorek and Wyszkowski (2016a), and that of manure by Kosiorek and Wyszkowski (2016a) in experiments with different plant species. In other research by Kosiorek and Wyszkowski (2016b), the most beneficial effect on soil properties was that of zeolite and calcium oxide. They caused an increase in soil $\mathrm{pH}$, total exchangeable bases, cation exchange capacity, and a decrease in hydrolytic acidity. Among other substances, charcoal had the strongest effect on soil properties. An increase in $\mathrm{pH}$ considerably reduced the toxicity of cobalt due to its binding by the solid phase of soil (Micó et al. 2008). According to Pshinko 
(2008), cobalt is weakly bound by the sorption complex, particularly due to the development of complex ions in the soil solution. The occurring sorption as well as desorption processes, concerning mainly calcium and magnesium cations, also have a substantial effect. Their initiation is determined to the greatest degree by soil reaction. Research by Collins and Kinsela (2010), similarly as that by Lange et al. (2014), shows substantial contribution of organic substances to an increase in $\mathrm{pH}$, and therefore a reduction of assimilable forms of cobalt occurring in the soil solution. According to Kwiatkowska and Maciejewska (2008), the introduction of carbon into soil contributes to the improvement of soil properties due to an increase in soil reaction and cation exchange capacity, and a reduction of hydrolytic acidity. The positive effect of zeolite on soil properties is confirmed in research by Glisic et al. (2009) and Jayasinghe et al. (2010).

\section{CONCLUSIONS}

1. The increasing doses of cobalt as well as manure, clay, charcoal, zeolite, and calcium oxide applied in the experiment substantially affected the $\mathrm{pH}$, hydrolytic acidity, total exchangeable bases, cation exchange capacity and base saturation.

2. In objects with no addition of substances, increasing cobalt doses reduced $\mathrm{pH}$ and increased the hydrolytic acidity of soil. The greatest decrease in total exchangeable bases was recorded in objects contaminated with 160 and $320 \mathrm{mg} \mathrm{Co} \cdot \mathrm{kg}^{-1}$ of soil. Increasing cobalt doses significantly contributed to a decrease in base saturation.

3. Among substances, calcium oxide had the most beneficial effect on soil properties. In objects with its addition, hydrolytic acidity was significantly reduced, and the remaining analysed soil properties were increased. Addition of manure proved to have an equally beneficial, although considerably weaker effect on the studied soil properties.

\section{ACKNOWLEDGEMENTS}

The study results were obtained in the scope of the faculty grant "Development of young scientists and participants of post-doctoral studies" financed from the resources of the Ministry of Science and Higher Education.

\section{REFERENCES}

Arimoto R., Duce R.A., Ray B.J., Uni C.K., 1985. Atmospheric trace elements at Enewetak Atoll, 2. Transport to the ocean by wet and dry deposition. Journal of Geophysical Research 90 (D1): 2391-2408.
Biswas S., Dey R., Mukherjee S., Banerjee P.C., 2013. Bioleaching of nickel and cobalt from lateritic chromite overburden using the culture filtrate of Aspergillus niger. Applied Biochemistry and Biotechnology 170(7): 1547-1559.

Chatterjee J., Chatterjee C., 2002. Amelioration of phytotoxicity of cobalt by high phosphorus and its with drawal in tomato. Journal of Plant Nutrition 25(12): 2731-2743.

Collins R.N., Kinsela A.S., 2010. The aqueous phase speciation and chemistry of cobalt in terrestrial environments. Chemosphere 79(8): 763-771.

Elinder C.G., 1984. Health hazards from exposure to cobalt with special reference to carcinogenic, mutagenic and teratogenic effects. Toxicogical and Environmental Chemistry 7: 251-256.

Glisic I.P., Milosevic T.M., Glisic I.S., Milosevic N.T., 2009. The effect of natural zeolitesand organic fertilisers on the characteristics of degraded soils and yield of crops grown in Western Serbia. Land Degradation and Development 20(1): 33-40.

Hansson H.C., Ekholm A.K.P., Ross H.B., 1988. Rainwater analysis: A comparison between proton induced $\mathrm{x}$-ray emission and graphite furnace atomic absorption spectroscopy. Environment Science and Technology 22: 527-531.

Hinojosa M.B., Dick R.P., Garcia-Ruiz R., Carreira J.A., 2004. Soil moisture pre-treatment effects on enzyme activities as indicators of heavy metal-contaminated and reclaimed soils. Soil Biology and Biochemistry 36(10): 1559-1568.

Hu Y., Liu X., Bai J., Shih K., Zeng E.Y., Cheng H., 2013. Assessing heavy metal pollution in the surface soils of a region that had undergone three decades of intense industrialization and urbanization. Environmental Science and Pollution Research 20(9): 6150-6159.

Huang L., Li T., Liu C., Quan X., Chen L., Wang A., Chen G., 2013. Synergetic interactions improve cobalt leaching from lithium cobalt oxide in microbial fuel cells. Bioresource Technology 128: 539-546.

Jain V., Nainawatee H.S., 2000. Cobalt reduces nitrate inhibition of nodulation in mungbean (Vigna radiata). Biology and Fertility of Soils 31(6): 522-524.

Jayasinghe G.Y., Tokashiki Y., Kinjo K., Liyana-Arachchi I.D., 2010. Evaluation of the use of Synthetic Red Soil Aggregates (SRA) and zeolite as substrate for ornamental plant production. Journal of Plant Nutrition 33(14): 2120-2134.

Kabata-Pendias A., Pendias H., 2001. Trace elements in soils and plants. 3 rd ed. CRC Press: Boca Raton, FL: 413 pp.

Kosiorek M., Wyszkowski W., 2016a. Effect of neutralising substances on selected properties of soil contaminated with cobalt. Journal of Ecological Engineering 17(3): 193-197.

Kosiorek M., Wyszkowski M., 2016b. Selected properties of cobalt-contaminated soil following the application of neutralising substances. Environmental Protection and Natural Resources 27 1(67): 22-25.

Kukier U., Peters C. A., Chaney R.L., Angle J.S., Roseberg R.J., 2004. The effect of $\mathrm{pH}$ on metal accumulation in two Alyssum species. Journal of Environmental Quality 33(6): 2090-2102.

Kwiatkowska J., Maciejewska A., 2008. Wpływ rodzajów substancji organicznej na właściwości fizykochemiczne gleby i zawartość węgla organicznego. Roczniki Gleboznawcze Soil Science Annual 59(1):128-133.

Lange B., Faucon M.P., Meerts P., Shutcha M., Mahy G., Pourret O., 2014. Prediction of the edaphic factors influence upon the copper and cobalt accumulation in two metallophytes using 
copper and cobalt speciation in soils. Plant and Soil 379(1): 275-287.

Li H.F., Gray C., Mico C., Zhao F. J., McGrath S. P., 2009. Phytotoxicity and bioavailability of cobalt to plants in a range of soils. Chemosphere 75(7): 979-986.

Li Z., McLaren R.G., Metherell A.K., 2004. The availability of native and applied soil cobalt to ryegrass in relation to soil cobalt and manganese status and other soil properties. New Zealand Journal of Agricultural Research 47(1): 33-43.

Łabętowicz J., Rutkowska B., 2001. Czynniki determinujące stężenie mikroelementów w roztworze glebowym. Postępy Nauk Rolniczych 6: 75-85.

Micó C., Li H.F., Zhao F.J., Mcgrath S.P., 2008. Use of Co speciation and soil properties to explain variation in Co toxicity to root growth of barley (Hordeum vulgare L.) in different soils. Environmental Pollution 156(3): 883-890.

Migaszewski Z.M., Gałuszka A., 2016. Geochemia środowiska. Wydawnictwo Naukowe PWN, Warszawa: 638 ss.

Nilsson K., Jensen B.S., Carlsen L., 1985. The migration chemistry of cobalt. European Applied Research 7: 23-86.

Ostrowska A., Gawliński S., Szczubiałka Z., 1991. Metody analizy i oceny właściwości gleb i roślin. Instytut Ochrony Środowiska, Warszawa. 333 ss.
Pshinko G.N., 2008. Impact of complexing agents on the processes of sorption treatment of waters containing cobalt. Journal of Water Chemistry and Technology 30(4): 197-202.

Rozporządzenie Ministra Środowiska z dnia 1 września 2016 roku w sprawie sposobu prowadzenia oceny zanieczyszczenia powierzchni ziemi (Dz.U. 2016, poz. 1395).

StatSoft, Inc. STATISTICA data analysis software system, version 12, www.statsoft.com, 2014.

Toxicological Profile for Cobalt., 2004. US Departament of Health and Human Services Agency for toxic Substances and Diseases Registry: 1-398.

Wyszkowski M., Sivitskaya V., 2015. Effect of different substances on some properties of soil contaminated with heating oil. Journal of Ecological Engineering 16(1): 62-66.

Wyszkowski M., Wyszkowska J., 2009. The effect of contamination with cadmium on spring barley (Hordeum vulgare L.) and its relationship with the enzymatic activity of soil. Fresenius Environmental Bulletin 18(7): 1046-1053.

Received: June 12, 2016

Accepted: September 6, 2017

Associated editor: B. Rutkowska

\title{
Wpływ obornika, iłu, węgla drzewnego, zeolitu i tlenku wapnia na wybrane wlaściwości gleby zanieczyszczonej kobaltem
}

\begin{abstract}
Celem badań było określenie wpływu: obornika, iłu, węla drzewnego, zeolitu i tlenku wapnia na pH, kwasowość hydrolityczną, sumę kationów zasadowych, pojemność wymiany kationów i stopień wysycenia kompleksu sorpcyjnego kationami zasadowymi gleby po wprowadzeniu kobaltu $\left(0,20,40,80,160,320 \mathrm{mg} \cdot \mathrm{kg}^{-1}\right.$ gleby). Zarówno wzrastające dawki kobaltu, jak i obornik, ił, węgiel drzewny, zeolit bądź tlenek wapnia wpłynęły istotnie na badane właściwości gleby. W obiektach bez dodatku substancji zanieczyszczenie gleby najwyższymi dawkami kobaltu obniżyło $\mathrm{pH}$, sumę kationów zasadowych i stopień wysycenia kompleksu sorpcyjnego kationami zasadowymi oraz zwiększyło kwasowość hydrolityczną gleby. Spośród substancji zastosowanych w celu neutralizacji zanieczyszczenia kobaltem najkorzystniej na analizowane właściwości gleby oddziaływał tlenek wapnia. W obiektach z jego dodatkiem kwasowość hydrolityczna uległa istotnemu obniżeniu, a pozostałe analizowane właściwości gleby zwiększeniu. Równie korzystnym, jednak znacznie słabszym oddziaływaniem na badane właściwości gleby odznaczał się dodatek w formie obornika.
\end{abstract}

Stowa kluczowe: kobalt, dawki, substancje, właściwości gleby 